\title{
Insulin receptor sensitization restores neocortical excitation/inhibition balance in a mouse model of autism
}

\author{
Fu-Sun Lo and Reha S. Erzurumlu*
}

\begin{abstract}
Background: Met receptor tyrosine kinase regulates neurogenesis, differentiation, migration, connectivity, and synaptic plasticity. The human Met gene has been identified as a prominent risk factor for autism spectrum disorder (ASD). Met gene-altered mice serve as useful models for mechanistic studies of ASD. Inactivation of Met in excitatory cortical neurons in mice (Emx ${ }^{\text {cre }} /$ Met $^{\text {flox }}$ mice) yields a phenotype in which significantly decreased $G_{A B A_{A}}$ receptor-mediated inhibition shifts the excitation/inhibition (E/I) balance toward excitation in the somatosensory cortex. Further, unlike that seen in wild-type mice, insulin does not increase inhibition in the mutant cortex, suggesting that one of the consequences of kinase inactive Met gene could be desensitization of insulin receptors. To test this hypothesis, we investigated the effects of insulin receptor sensitizer, pioglitazone, on inhibition in the somatosensory thalamocortical circuitry.

Methods: We used whole-cell patch clamp electrophysiology and analyzed excitatory and inhibitory responses of cortical layer IV excitatory cells following stimulation of their thalamic input in thalamocortical pathway intact brain slices. We applied insulin alone and insulin + a thiazolidinedione, pioglitazone (PIO), to test the effects of sensitizing insulin receptors on inhibitory responses mediated by $\mathrm{GABA}_{\mathrm{A}}$ receptors in the somatosensory cortex of $\mathrm{Em \times 1} 1^{\mathrm{cr}} / \mathrm{Met}^{\text {flox }}$ mice.

Results: In WT brain slices, application of insulin together with PIO did not enhance the effect of insulin alone. In contrast, $\mathrm{PIO}$ application induced a much larger inhibition than that of insulin alone in Met-defective cortex. Thus, insulin resistance of $\mathrm{GABA}_{\mathrm{A}}$ receptor-mediated response in Met mutant mice may result from desensitized insulin receptors.

Conclusions: Sporadic clinical studies reported improved behavioral symptoms in children with autism following PIO treatment. We show that PIO can aid in normalization of the E/I balance in the primary somatosensory cortex, a potential physiological mechanism underlying the positive effects of $\mathrm{PIO}$ treatment.
\end{abstract}

Keywords: Met receptor tyrosine kinase, Barrel cortex, Homeostatic plasticity, GABA A receptors, Pioglitazone, Thalamocortical circuitry

\section{Background}

Numerous studies have associated Met gene as a of a functional risk allele in autism spectrum disorders (ASD) [1-3]. The Met receptor tyrosine kinase is a multifunctional receptor with diverse biological roles activating various intracellular signaling pathways. Met mutations in mice provide models to investigate cellular and molecular deficits in the nervous system. One such line, $E m x 1^{\text {cre }} / \mathrm{Met}^{\text {flox }}$ mice (from here on referred to as Met-Emx1 mouse), has kinase-

\footnotetext{
* Correspondence: rerzurumlu@som.umaryland.edu

Department of Anatomy and Neurobiology, University of Maryland School of

Medicine, 22 Penn Street HSFII-S259, Baltimore, MD 21201, USA
}

inactive Met gene in excitatory neurons of the neocortex, hippocampus, and olfactory bulbs $[4,5]$. For cortical studies, these mice may be considered as cortex-specific null mutation of Met. Previously, we reported that in thalamocortical brain slices from Met-Emx1 mice the E/I ratio is biased toward excitation in the primary somatosensory cortex due to decreased $\mathrm{GABA}_{\mathrm{A}}$ receptor-mediated inhibition [6]. Excitation-inhibition (E/I) balance in neural circuits is a type of homeostatic synaptic plasticity that is notably affected in various neurological and psychiatric conditions $[7,8]$.

Insulin receptors are abundant in the brain $[9,10]$, and insulin regulates GABAergic inhibition by increasing the 
density of $\mathrm{GABA}_{\mathrm{A}}$ receptors, consequently augmenting inhibitory postsynaptic currents [11, 12]. In our study, we found that in wild-type (WT, C57BL/6) brain slices insulin enhances $\mathrm{GABA}_{\mathrm{A}}$ receptor-mediated response. In contrast, insulin treatment had no effect on slices from $E m x 1^{\text {cre }} /$ Met ${ }^{f l o x}$ mice [6]. To determine whether sensitizing insulin receptors can enhance $\mathrm{GABA}_{\mathrm{A}}$ receptor-mediated response, we tested pioglitazone (PIO) treatment. PIO is a widely used thiazolidinedione that acts as an insulin-sensitizer through activation of the peroxisome proliferator-activated receptor- $\gamma$ [13]. There are two members of the class thiazolidinediones that have been used as insulin sensitizers in treatment of type 2 diabetes: pioglitazone (Actos) and rosiglitazone (Avandia). We have chosen to use PIO because it is the most widely used and rosiglitazone has yielded lessdesirable effects. Furthermore, few clinical studies have reported improved symptoms in neurodevelopmental and neurogeriatric conditions following PIO treatment [14-20]. In the future, testing different members of this drug family under in vivo conditions could yield important insights. In WT thalamocortical slices, application of insulin plus PIO did not enhance the effect of insulin alone. However, this treatment induced a much larger inhibition than that of insulin alone in Met-Emx1 mice. This finding indicates that the insulin resistance of $\mathrm{GABA}_{\mathrm{A}}$ receptor-mediated response in Met-Emx1 mice mainly results from desensitized insulin receptors.

\section{Methods}

\section{Animals}

The brain slices were derived from Met-Emx1 mice of both sexes $(n=5)$. We obtained these mice through crossings of the floxed Met mouse (Met-fx) with the cerebral cortical and hippocampal specific Emx1-cre mouse. Our original sources and further details of the mouse lines are detailed in a previous paper [6], currently both lines are commercially available (Met-fx stock \#016974, Emx1-Cre, stock \#005628, Jackson Laboratory, Bar Harbor, ME). Control brain slices were from mice with Met-fx or Emx1-cre alleles alone or C57BL/6 (the background of the mutant line) mice $(n=5)$. There were no differences between the three types of control slices. For mouse use, we followed the National Institute of Health Guide for the Care and Use of Laboratory Animals (ISBN:13:978-0-309-15400-0, revised in 2011) and the UMB SOM Animal Use and Care Committee approved our protocol.

\section{Brain slice preparation}

Two- to 4-week-old mice were euthanized and their brains removed into cold sucrose supplemented with artificial cerebrospinal fluid (ACSF, in mM: $\mathrm{NaHCO}_{3} 25$, glucose 11, sucrose 234, $\mathrm{KCl} 2.5, \mathrm{NaHPO}_{4} 1.25, \mathrm{MgSO}_{4}$ 10). Next, we cut $350-\mu \mathrm{m}$-thick thalamocortical pathway intact brain slices using a vibratome (Campden $7000 \mathrm{msz}$ ), at an angle of $50-55^{\circ}$ from the mid-sagittal plane and $10^{\circ}$ from the coronal plane [21, 22]. In such slices, the connections from the ventrobasal nucleus of the thalamus (VB) to the primary somatosensory, specifically the whisker representation zone, the barrel cortex, remain intact. We kept the slices in normal ACSF (in mM: $\mathrm{NaCl} \mathrm{126,} \mathrm{KCl} 3.0$, $\mathrm{NaH}_{2} \mathrm{PO}_{4}$ 1.25, $\mathrm{MgSO}_{4}$ 1.0, $\mathrm{NaHCO}_{3} 26$, glucose 10, $\mathrm{CaCl}_{2}$ 2, L-ascorbic acid 1.3, $\mathrm{pH}=7.4$ ) for at least $1 \mathrm{~h}$, at room temperature. We placed the slice containing the thalamocortical pathway in a submerged-type recording chamber (27 L, Warner Ins.), and continuously perfused $(>2 \mathrm{~mL} / \mathrm{min}$ ) with normal ACSF at room temperature. Under these conditions, intra-cortical circuits are inactivated, and the excitatory thalamocortical synapses on layer IV neurons can be isolated [23].

\section{Thalamocortical slice electrophysiology}

We prepared borosilicate glass (WPI, K150F-4) whole-cellpatch micropipettes by pulling them in three stages with a P-87 horizontal puller (Sutter Instrument Co.). We backfilled the electrodes with a Cs-based intracellular solution (in mM: $\mathrm{CsMeSO}_{3}, 115 ; \mathrm{NaCl}, 10 ; \mathrm{KCl}, 1, \mathrm{MgCl}_{2}, 4 ; \mathrm{CaCl}_{2}$, 1; EGTA, 11; HEPES, 20; $\mathrm{Na}_{2}$-ATP, 3; $\mathrm{Na}_{2}$-GTP, 0.5, $\mathrm{pH}=$ $7.25,>290 \mathrm{mOsm})$. The electrodes had a tip resistance of 5-9 M $\Omega$. Spiny stellate and star pyramid cells are the excitatory neurons of layer IV barrel cortex. We patched these neurons to form whole-cell configuration. We passed depolarizing current pulses through the patch pipette in current clamp mode to identify the cells by their firing patterns [24-26]. For stimulation of the thalamocortical afferents, we used a concentric electrode (FHC, CBFP J50) either inserted in the VB, which can be visualized in slices or in the internal capsule (IC). We passed $0.33 \mathrm{~Hz}$ electrical pulses for $0.3 \mathrm{~ms}$ duration, $0.33 \mathrm{~Hz}$ to evoke postsynaptic responses in both current- and voltage-clamp modes. We acquired the by Axopatch 200B amplifier and an InstruTECH ITC-16 interface unit and stored on a Dell DM061 computer with PULSE (HEKA) software program.

\section{Isolation of $\mathrm{GABA}_{\mathrm{A}}$ receptor- and AMPA receptor- mediated postsynaptic currents}

At $-60 \mathrm{mV}$ holding potential, stimulation of the VB elicits an early inward current (excitatory postsynaptic current, EPSC) followed by an outward current (inhibitory postsynaptic current, IPSC). As we move the holding potential toward more negative values, the outward current becomes smaller, and when this current disappears around $-70 \mathrm{mV}$ holding potential, we define this as the $\mathrm{GABA}_{\mathrm{A}}$ receptor reversal potential. In the absence of any NMDA receptor blockade, the remaining inward current is pure AMPA receptor-mediated EPSC. This inward current can be blocked by $10 \mu \mathrm{M}$ NBQX, but not by $50 \mu \mathrm{M}$ picrotoxin (PTX). Changing the holding potential toward more positive values decreased the amplitude of the 
inward current and it disappeared around $0 \mathrm{mV}$ holding potential, which we defined as the reversal potential for glutamate receptors. The resulting outward current could be completely blocked by $50 \mu \mathrm{M}$ PTX but not by $100 \mu \mathrm{M}$ DL$\mathrm{APV}$; thus, it is the isolated $\mathrm{GABA}_{\mathrm{A}}$ receptor-mediated IPSC. We calculated the ratio of AMPA/GABA (E/I) for each neuron by averaging 10 traces of EPSCs and IPSCs induced by maximal stimulation.

\section{$\mathrm{GABA}_{\mathrm{A}}$ receptor-mediated spontaneous IPSCs (sIPSCs)}

We recorded spontaneous IPSCs at $0 \mathrm{mV}$. We measured the averaged amplitude of sIPSCs using MiniAnalysis Software.

\section{Chemicals}

Insulin (500 $\mathrm{nM}$ ), pioglitazone (PIO, $10 \mu \mathrm{M})$, an insulin receptor sensitizer, NBQX $(10 \mu \mathrm{M})$, an AMPA receptor antagonist, DL-APV $(100 \mu \mathrm{M})$, a NMDA receptor antagonist, and PTX $(50 \mu \mathrm{M})$, a $\mathrm{GABA}_{\mathrm{A}}$ receptor antagonist were applied as needed. All chemicals are purchased from Sigma-Aldrich Co. (St. Louis, MO).

\section{Data analysis}

We used Student's $t$ test to determine significance. All data are expressed by mean \pm s.e.m. (standard error of the mean). Box and whisker plots were generated in $\mathrm{R}$ studio version 1.1.419.

\section{Results}

\section{Functional insulin receptors in the barrel cortex of WT} mice

Previously, we investigated the thalamocortical synaptic transmission in the barrel cortex of various lines of transgenic and WT mice $[6,27,28]$. In complete agreement with those studies, layer IV excitatory neurons show adapting discharges (regular spikes, RS) upon membrane depolarization (Fig. 1a-c). Stimulation of VB induces an excitatory postsynaptic potential-inhibitory postsynaptic potential (EPSP-IPSP) sequence. At membrane potential of $-60 \mathrm{mV}$, the IPSP just curtails the
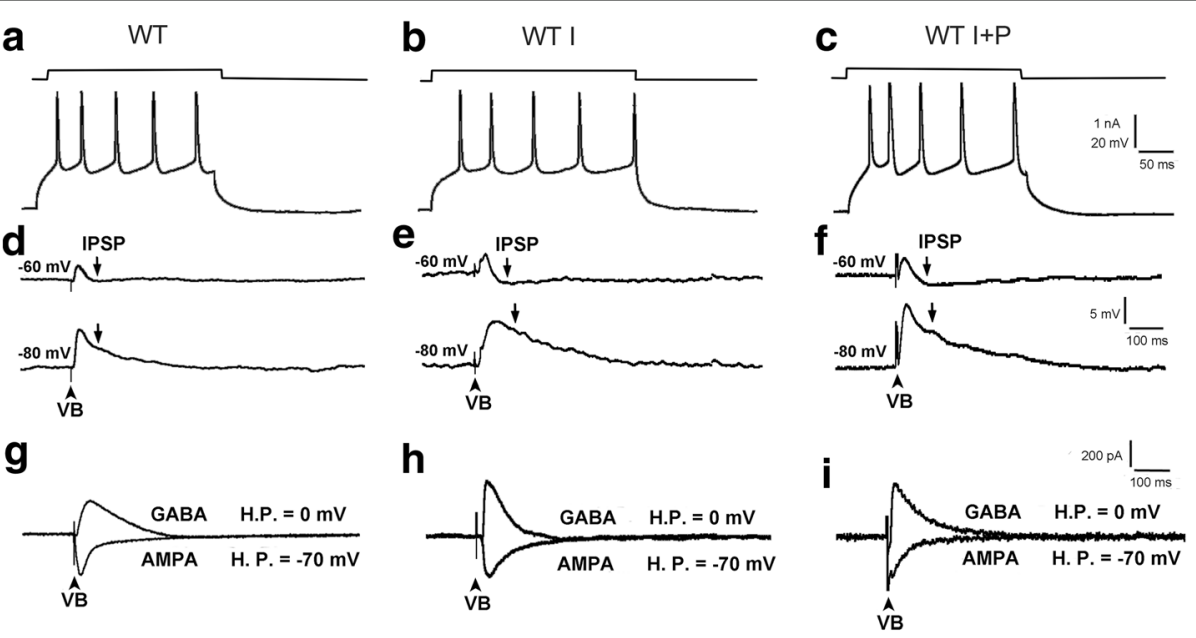

h
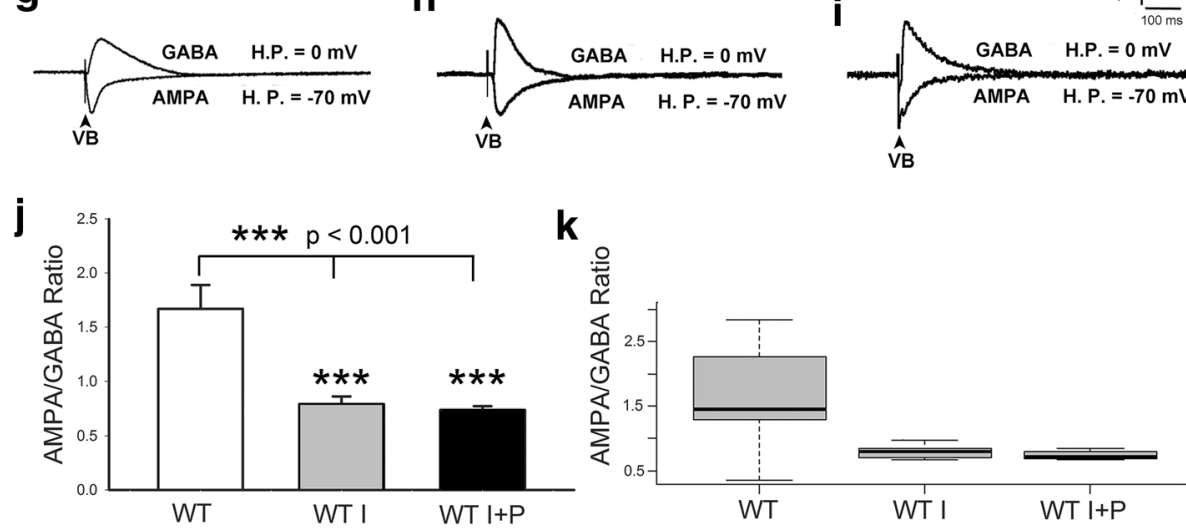

Fig. 1 Insulin and pioglitazone treatment effects on the E/I ratio in WT brain slices. a-c Membrane depolarization characteristically leads to regular spiking of layer IV excitatory neurons. This characteristic is evident in control (WT) slices, and after application of insulin (WT I), or insulin + pioglitazone (WT I + P). d EPSP-IPSP sequence following VB stimulation. At $-60 \mathrm{mV}$, the IPSP does not hyperpolarize below - $60 \mathrm{mV}$ (upper trace). The IPSP polarity reverses at $-80 \mathrm{mV}$, around $\mathrm{GABA}_{\mathrm{A}}$ receptor reversal potential (lower trace). e $500 \mathrm{nM}$ insulin application results in an increase of IPSP that hyperpolarized below base line at $-60 \mathrm{mV}$ (upper trace). The IPSP is mediated by GABA receptor, because it reverses at $-80 \mathrm{mV}$ (lower trace). f Addition of pioglitazone to insulin application does not lead to any notable change. $\mathbf{g}$-i Representative records of $G A B A_{A}$ receptor- and AMPA receptor-mediated currents under control, insulin, and insulin + pioglitazone application conditions. HP holding potential. $\mathbf{j}$ The averaged AMPA/GABA (E/I) ratios under the three conditions. Note that insulin application significantly reduces the E/l ratio; addition of pioglitazone does not change insulin effects alone. $\mathbf{k}$ Box and whisker plots showing the population distribution 
EPSP but does not hyperpolarize below - $60 \mathrm{mV}$ (Fig. 1d, upper trace). The IPSP is reversed in polarity at $80 \mathrm{mV}$, suggesting that it is mediated by $\mathrm{GABA}_{\mathrm{A}}$ receptor with a reversal potential around $-70 \mathrm{mV}$ (Fig. 1d, lower trace).

In WT thalamocortical slices, application of $500 \mathrm{nM}$ insulin resulted in an increase of IPSP that hyperpolarized below base line at $-60 \mathrm{mV}$ (Fig. 1e, WT I, upper trace). The IPSP was also mediated by $\mathrm{GABA}_{\mathrm{A}}$ receptor, because it reversed at $-80 \mathrm{mV}$ (Fig. 1e, lower trace). In order to quantify the changes in E/I ratio, we voltageclamped each cell to the reversal potential of $\mathrm{GABA}_{\mathrm{A}}$ receptors (around $-70 \mathrm{mV}$ ) and AMPA receptors (around $0 \mathrm{mV}$ ) so that we could record $\mathrm{GABA}_{\mathrm{A}}$ receptor- and AMPA receptor-mediated currents $(1 ; 25)$. Figure $1 \mathrm{~g}, \mathrm{~h}$ are representative records. The averaged AMPA/GABA (E/I) ratio for control WT mice was $1.67 \pm 0.22(n=11$, Fig. 1 j, k), while insulin significantly $(p<0.001)$ reduced the ratio to $0.79 \pm 0.07 \quad(n=7$, Fig. 1j, k). To test whether the effect of insulin can be further enhanced by insulin receptor sensitizer PIO, we applied both $500 \mathrm{nM}$ insulin and $10 \mu \mathrm{M}$ PIO $(\mathrm{I}+\mathrm{P})$ to the in vitro preparation. The results were largely similar to those obtained with insulin application alone (Fig. 1c, $\mathrm{f}, \mathrm{i}, \mathrm{j}, \mathrm{k})$. The averaged AMPA/GABA ratio was $0.74 \pm$ $0.03(n=6$, Fig. $1 \mathrm{j}, \mathrm{k})$, which is about the same as insulin alone $(p>0.53)$. Thus, PIO did not increase the effect of insulin on $\mathrm{GABA}_{\mathrm{A}}$ receptor-mediated response in WT slices, suggesting that insulin receptors are saturated by $500 \mathrm{nM}$ insulin.

To investigate the mechanism underlying insulininduced increased inhibition, we recorded $\mathrm{GABA}_{\mathrm{A}}$ receptor-mediated spontaneous IPSCs (sIPSCs) as shown in Fig. $2 \mathrm{a}-\mathrm{c}$. The cumulative fraction curves of the amplitude of sIPSCs (Fig. 2d) show that the amplitude distribution for WT I (medium thickness line) and WT I + P (thick line) is shifted to the right (larger amplitude) than that of no insulin controls (WT, thin line). This indicated that insulin (I) and insulin + PIO (I + P) increased the amplitude of sIPSCs. The difference between WT I
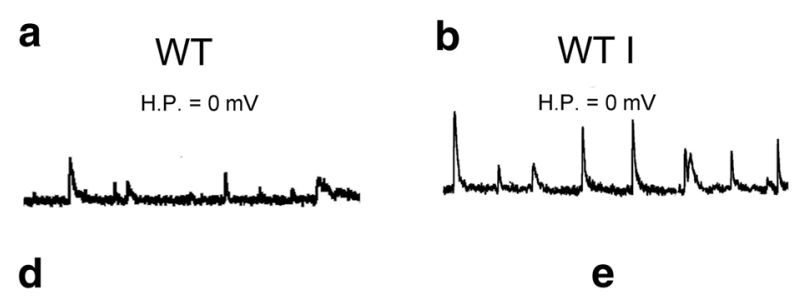

C WT I+P
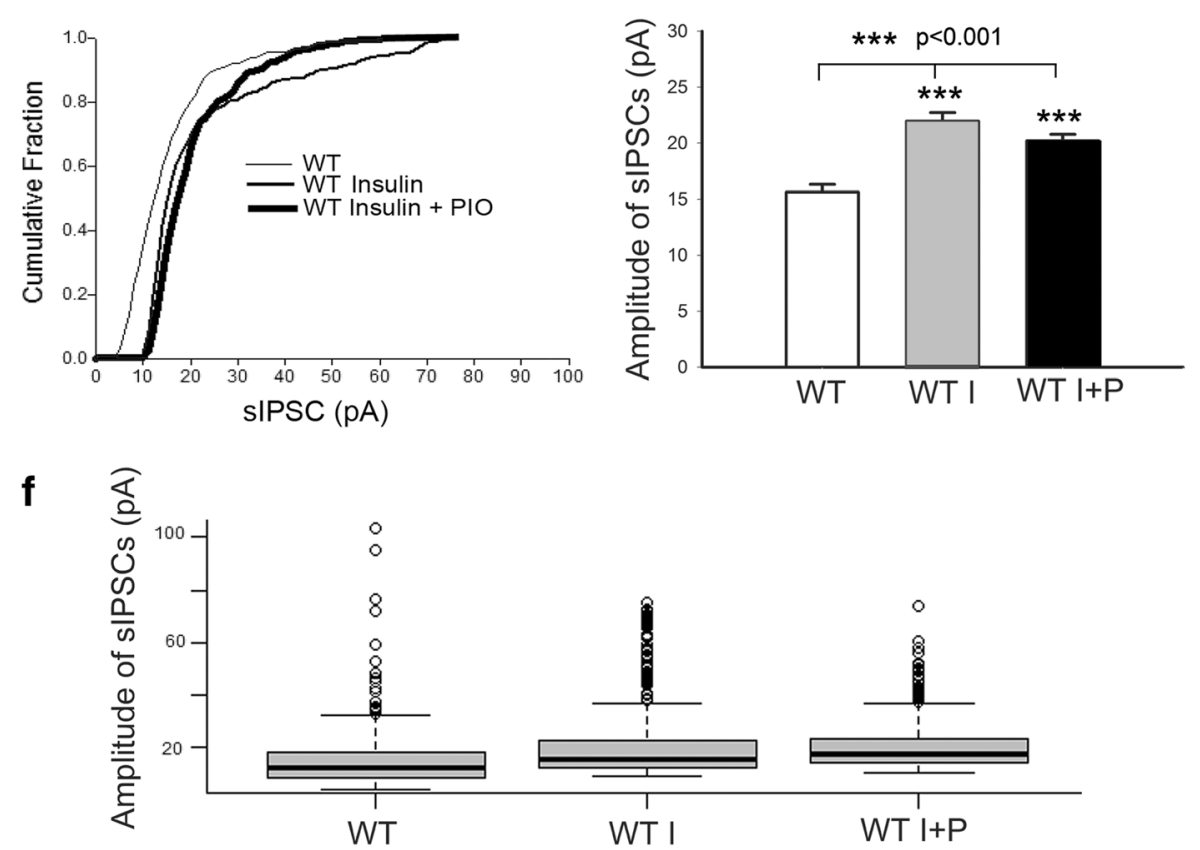

Fig. 2 Insulin-induced increased inhibition. a-c Example records of GABA $A_{A}$ receptor-mediated sIPSCs. HP holding potential. d Cumulative fraction curves of the sIPSC amplitudes show that the amplitude distribution for insulin (WT I) and insulin + pioglitazone (WT I + P) are shifted to the right (larger amplitude), indicating that both conditions increase the amplitude of sIPSCs compared to no drug controls. e The average amplitude of sIPSCs is higher with either drug application condition compared to the controls, but not different between the two drug application conditions. $\mathbf{f}$ Box and whisker plots showing the population distribution 
and WT I $+\mathrm{P}$ curves resulted from the difference in amplitude distribution. WT I + P group had less (12\%) larger (> $30 \mathrm{pA}$ ) sIPSCs and WT I group had (19\%) larger sIPSCs. However, the averaged amplitude of sIPSCs for WT I and WT I + P (Fig. 2e, f) showed no significant difference $(p>0.08)$, because the averaged amplitude of sIPSCs of WT I was $22.00 \pm 0.76(n=434) \mathrm{pA}$, while that for WT I + P was $20.22 \pm 0.56(n=319)$. Both of them were significantly $(p>0.001)$ larger than the WT group $(15.64 \pm 0.68 \mathrm{pA}, n=320)$.

\section{Insulin receptors are desensitized in the barrel cortex of Met-Emx1 mice}

Layer IV of barrel cortex excitatory neurons of Met$E M x 1$ mice also show regular spiking upon membrane depolarization (Fig. 3a-c). Stimulation of VB induced mainly an EPSP without a clear cut IPSP in $M e-E m x 1$ mice (Fig. 3d). Isolated AMPA receptor- and $\mathrm{GABA}_{\mathrm{A}}$ receptor-mediated currents revealed a relatively smaller IPSC (Fig. 3g). The averaged AMPA/GABA ratio for Met-Emx1 mice was $3.53 \pm 0.43(n=8$, Fig. 3 j, k), which is significantly $(p<0.001)$ larger than that of the WT mice $(1.67 \pm 0.22)$. In contrast to the WT slices, application of insulin (Met-Emx1 I) did not change the magnitude of $\mathrm{GABA}_{\mathrm{A}}$ receptor-mediated response (Fig. 3e, h, $\mathrm{j}, \mathrm{k})$. The averaged AMPA/GABA ratio was $3.53 \pm 0.42$ $(n=5)$ that was just the same as without insulin $(p>$ 0.99). The failure of insulin effect on inhibition may result from desensitized insulin receptors; thus, we applied PIO together with insulin (Met I $+\mathrm{P})$. Representative records (Fig. 3f, i) demonstrated that addition of PIO increased $\mathrm{GABA}_{\mathrm{A}}$ receptor-mediated inhibition so that the averaged AMPA/GABA ratio was $0.69 \pm 0.08 \quad(n=5)$, which is significantly $(p<0.001)$ smaller than previous groups (Fig. 3j, k).

We also recorded $\mathrm{GABA}_{\mathrm{A}}$ receptor-mediated sIPSCs in Met-Emx1 mice. Representative records (Fig. 4a-c) showed that the amplitudes of sIPSCs increased only during application of insulin plus PIO (Fig. 4c). The cumulative fraction curves for Met-Emx1 and Met-Emx1 I were about the same (Fig. $4 \mathrm{~d}$, thin and medium lines). However, the curve for Met-Emx1 I + P was shifted to the right, the larger amplitude area (Fig. $4 \mathrm{~d}$, thick line). The averaged amplitude of sIPSCs for Met-Emx1 mice a $\quad M e t-E m \times 1$

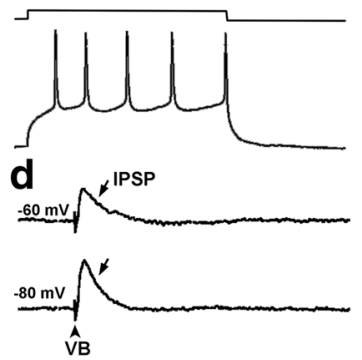

g

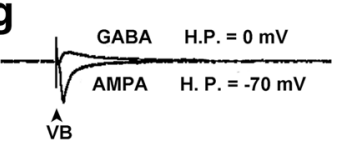

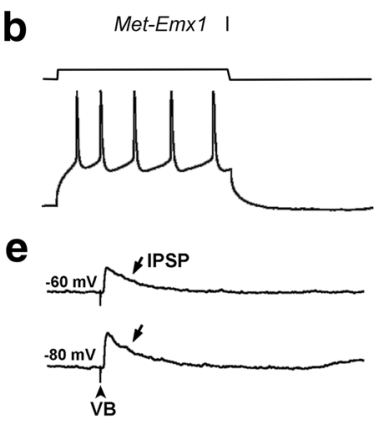

h

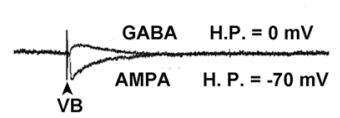

C Met-Emx1 $1+\mathrm{P}$

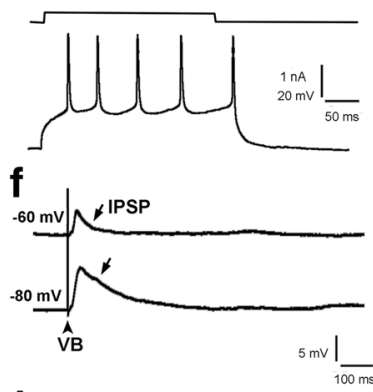

i

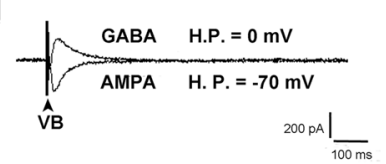

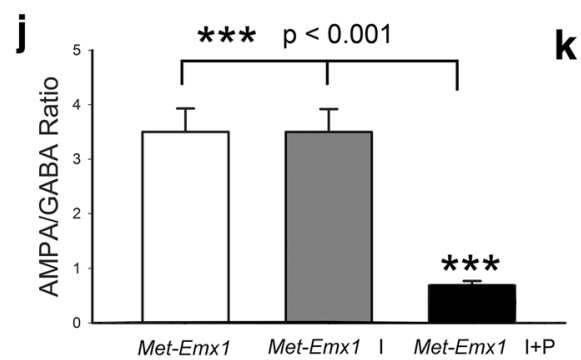

$\mathbf{k}$

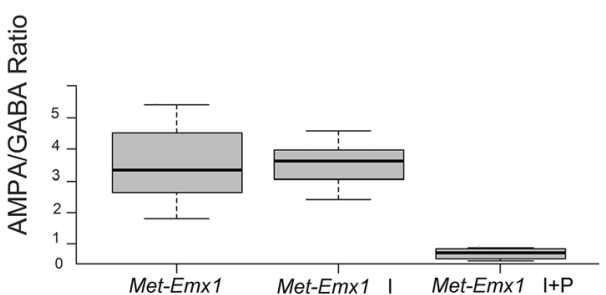

Fig. 3 Insulin and pioglitazone treatment effects on the E/I ratio in Met-EMx1 brain slices. a-c Regular spiking of layer IV excitatory neurons in control (Met-EMx1) slices, and after application of insulin (Met-EMx1 I), or insulin + pioglitazone (Met-EMx 1 I+P). $\mathbf{d}, \mathbf{g}$ In mutant brain slices, stimulation of VB induced mainly an EPSP without a clear cut IPSP. Isolated AMPA receptor- and GABA $A_{A}$ receptor-mediated currents reveal small IPSC. $\mathbf{e}, \mathbf{h}$ Application of insulin (Met-EMX1 I) did not change the magnitude of GABA $A_{A}$ receptor-mediated response. $\mathbf{f}$, i Addition of pioglitazone to insulin application dramatically increased $G_{A B A}$ receptor-mediated inhibition. $\mathbf{j}$ The averaged AMPA/GABA (E/I) ratio is similar between no drug treatment and insulin alone treatment conditions, but application of pioglitazone along with insulin dramatically changed this ratio. $\mathbf{k}$ Box and whisker plots showing the population distribution 

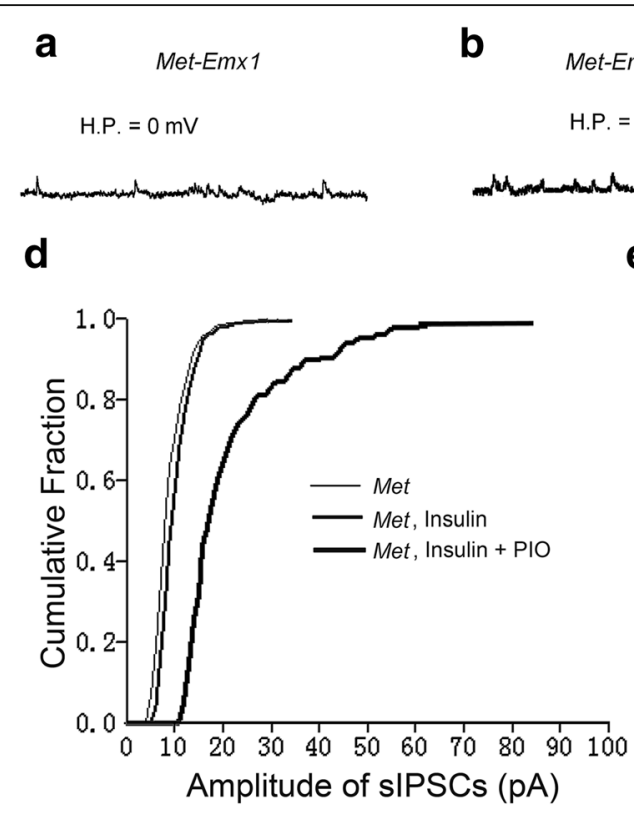

e
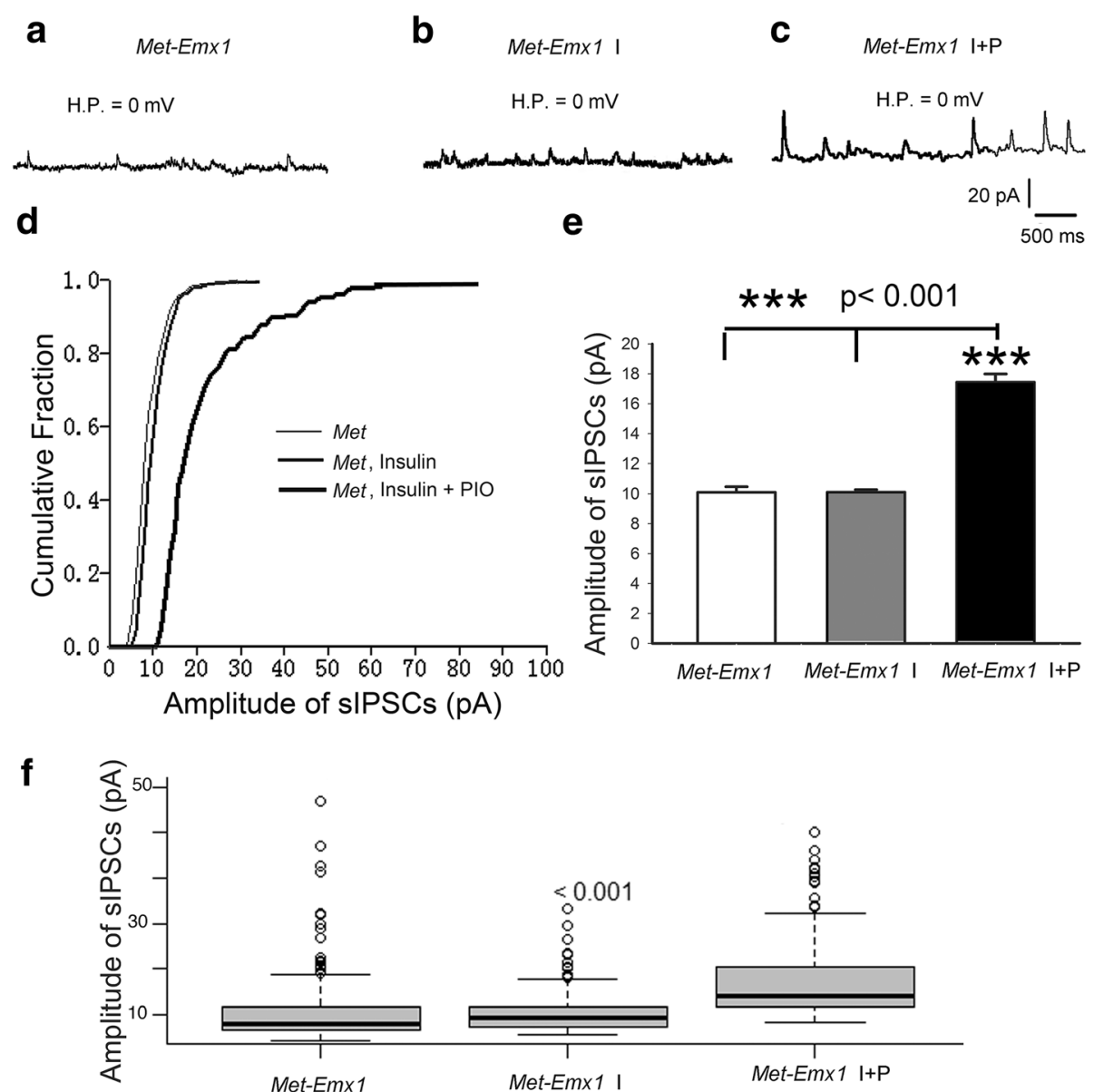

Fig. 4 Insulin sensitization-increased inhibition in Met-EMx1 brain slices. a-c Example records of GABA $A_{A}$ receptor-mediated sIPSCs in Met-EMx1 cortical neurons without drug application, and with insulin alone (I) or insulin + pioglitazone $(I+P)$ applications. $\mathbf{d}$ Cumulative fraction curves of the sIPSC amplitudes show a significant shift of the amplitude distribution for insulin + pioglitazone condition compared to no drug treatment (Met-EMX1) or insulin treatment (Met-EMX1 I) alone. e The average amplitude of sIPSCs is much higher following insulin receptor sensitization with pioglitazone. $\mathbf{f}$ Box and whisker plots showing the population distribution

was $10.10 \pm 0.37 \mathrm{pA}(n=295$, Fig. $4 \mathrm{e}, \mathrm{f})$ that was significantly $(p<0.001)$ smaller than that of WT mice $(15.64 \pm$ $0.68 \mathrm{pA})$. However, application of insulin (Met I) did not change $(p>0.97)$ the averaged amplitude of sIPSCs $(10.11 \pm 0.17 \mathrm{pA}, n=470$, Fig. 4e, f), suggesting insulin resistance of $\mathrm{GABA}_{\mathrm{A}}$ receptor-mediated response. Additional PIO together with insulin remarkably $(p<0.001)$ increased the amplitude of sIPSCs to $17.44 \pm 0.55 \mathrm{pA}$ ( $n$ $=235$, Fig. $4 \mathrm{e}, \mathrm{f})$ that was still smaller $(p<0.001)$ than WT I + P $(20.22 \pm 0.56 \mathrm{pA})$. These suggest that insulin receptors are desensitized in Met-Emx1 mice. The density of insulin receptors in Met-Emx1 mice may be lower than that in WT mice.

\section{Discussion}

E/I balance in neural circuits is an essential component of homeostatic synaptic plasticity, which is thought to restrain cortical network activity to operate at optimal levels by weakening synaptic efficacy after heightened activity and increasing it after low levels of activation [29]. A disturbed E/I balance, particularly in neocortical circuits, has been proposed and observed in ASD individuals and in animal models [7, 30, 31].

In neurodevelopmental disorders, failure in neuronal differentiation [32], defects in neurotransmitter release, and their postsynaptic receptors [33-35] have been linked to altered E/I balance. In neocortical circuits, interactions between Gamma-aminobutyric acidergic (GABAergic) interneurons and glutamatergic pyramidal neurons that form the corticocortical, callosal, and subcortical connections have been targeted by numerous studies seeking to unveil the circuit defects in disorders with cognitive symptoms. GABAergic neurons are a small population of neocortical residents, but they control inhibition of the most populous excitatory cortical neurons. Defects in differentiation of GABAergic 
interneurons, GABAergic synaptic transmission, and postsynaptic receptors have been the usual suspects in altered excitability and homeostatic plasticity of neural circuits.

Met receptor tyrosine kinase is a cell surface receptor activated by hepatocyte growth factor (HGF). For obvious reasons, Met and HGF signaling have been extensively studied in the liver. Met is structurally related to the insulin receptor tyrosine kinase and Met signaling is essential in regulation of insulin response by hepatocytes [36]. In fact, a potential therapeutic role for HGF treatment for insulin resistance in type 2 diabetes has been suggested [36]. A more recent study on cell cocultures and in knockout mice brings conclusive evidence for Met regulation of insulin sensitivity [37]. While both Met and HGF are expressed in a spatiotemporal specificity in the brain (reviewed in [1]), there are no studies examining any link between Met signaling and insulin sensitivity in neocortical excitatory neurons and how lack of it might affect GABAergic synaptic transmission.

In the primary somatosensory cortex of mice, with inactive autism-associated Met receptor tyrosine kinase, we found that increased excitation is due to decreased postsynaptic inhibition mediated via the $\mathrm{GABA}_{\mathrm{A}}$ receptors [6]. Altered $\mathrm{GABA}_{\mathrm{A}}$ receptor function can directly affect the $\mathrm{E} / \mathrm{I}$ balance. In transgenic mice lacking the $\beta 3$ subunit of the $\mathrm{GABA}_{\mathrm{A}}$ receptor (Gabrb3), seizure susceptibility, hypersensitivity, hyperactivity, learning, and memory deficits have been reported [38, 39]. In fragile $X$ mouse models too, decreased $\mathrm{GABA}_{\mathrm{A}}$ receptor expression has been observed [40-42]. A potential strategy to ameliorate decreased $\mathrm{GABA}_{\mathrm{A}}$ receptor function is to increase receptor sensitivity. In cultured hippocampal neuron, application of insulin increased $\mathrm{GABA}_{\mathrm{A}}$ receptormediated response $[43,44]$. We confirmed this response in thalamocortical slices taken from WT mice [6]. However, in thalamocortical slices from MetEmx1 mice, insulin application did not change $\mathrm{GABA}_{\mathrm{A}}$ receptor-mediated response, suggesting that there might be insulin resistance in neocortical neurons that lack Met function [6]. In the present study, we show that insulin resistance of $\mathrm{GABA}_{\mathrm{A}}$ receptormediated response in Met-Emx1 mice can be altered by insulin sensitization. We find that application of PIO, a common insulin sensitizer used in diabetes therapy, can significantly alter the $\mathrm{GABA}_{\mathrm{A}}$ receptor response and restore $\mathrm{E} / \mathrm{I}$ balance to levels of normalcy. At the present time, we do not know how Met deficiency in excitatory cortical neurons alters receptor desensitization or the intracellular signaling pathways involving insulin receptors. Further studies are needed to investigate these mechanisms in a cell type-specific manner to determine whether Met signaling through insulin receptors occurs in similar ways between the neocortical excitatory neurons and hepatocytes.

\section{Conclusions}

Excitation/inhibition balance is altered in favor of excitation in the primary somatosensory cortex of mice with inactive autism-associated Met receptor tyrosine kinase. Altered E/I balance, in favor of excitation, in the somatosensory cortex of mice with inactive autism-associated Met receptor tyrosine kinase may relate to somatic sensory hypersensitivity of children with ASD to shoes and clothing. We applied insulin alone and insulin + pioglitazone (PIO) to test the effects of sensitizing insulin receptors on inhibitory responses mediated by $\mathrm{GABA}_{\mathrm{A}}$ receptors in the thalamocortical circuitry of $E m x 1^{\text {cre }} / M e t^{\text {flox }}$ mice. We show that PIO can aid in normalization of the E/I balance in the primary somatosensory cortex, a potential physiological mechanism underlying the positive effects of PIO treatment in ASD patients. Our results shed light to the underlying mechanisms and suggest that decreased $\mathrm{GABA}_{\mathrm{A}}$ receptor activity is the major culprit in scaling E/I balance to more excitation and that insulin sensitization can help in readjusting the balance.

\section{Abbreviations \\ ACSF: Artificial cerebrospinal fluid; AMPA: a-Amino-3-hydroxy-5-methyl-4- isoxazolepropionic acid; ASD: Autism spectrum disorder; C57BL/6: Most widely used inbred mouse strain; DL-APV: DL-2-Amino-5- phosphonopentanoic acid; E/l: Excitation/inhibition; Emx1: Empty spiracles homeobox; EPSC: Excitatory postsynaptic current; GABA : Ionotropic receptor and $\gamma$-aminobutyric acid-gated ion channel; Gabrb3: $\beta 3$ subunit of the $G_{A B A_{A}}$ receptor; HGF: Hepatocyte growth factor; I + P: Insulin + pioglitazone; I: Insulin; IPSC: Inhibitory postsynaptic current; Met: Tyrosine-protein kinase Met or hepatocyte growth factor receptor; NBQX: 2,3-Dihydroxy-6-nitro-7- sulfamoyl-benzo(F) quinoxaline, potent AMPA receptor antagonist; NMDA: N- methyl-D-aspartate; PIO: Pioglitazone; PTX: Picrotoxin; SIPSC: Spontaneous inhibitory synaptic current; VB: Ventrobasal nucleus of thalamus; WT: Wild type (B6 mice)}

\section{Acknowledgements}

We thank Dr. Elizabeth Powell for introducing us to the autism model mice and discussions on the cortical phenotypes of the Met mutant mice.

\section{Funding}

Research supported by NIH/NINDS R01 NS092216

\section{Availability of data and materials}

The mice used in this study are commercially available. Electrophysiological data are available from the corresponding author on reasonable request.

\section{Authors' contributions}

FSL and RSE designed the study. FSL performed the experiments. FSL and RSE interpreted the results and wrote the manuscript. Both authors read and approved the final manuscript.

\section{Ethics approval}

All protocols strictly conformed to the National Institute of Health Guide for the Care and Use of Laboratory Animals (ISBN:13:978-0-309-15400-0, revised in 2011) and were approved by the University of Maryland Baltimore Institutional Animal Care and Use Committee. 


\section{Consent for publication}

Not applicable

\section{Competing interests}

The authors declare that they have no competing interests.

\section{Publisher's Note}

Springer Nature remains neutral with regard to jurisdictional claims in published maps and institutional affiliations.

Received: 1 September 2017 Accepted: 19 January 2018 Published online: 22 February 2018

\section{References}

1. Eagleson $\mathrm{KL}$, Xie Z, Levitt P. The pleiotropic MET receptor network: circuit development and the neural-medical interface of autism. Biol Psychiatry. 2017:81:424-33.

2. Peng Y, Lu Z, Li G, Piechowicz M, Anderson M, Uddin Y, et al. The autismassociated MET receptor tyrosine kinase engages early neuronal growth mechanism and controls glutamatergic circuits development in the forebrain. Mol Psychiatry. 2016;21:925-35.

3. Xie Z, Li J, Baker J, Eagleson KL, Coba MP, Levitt P. Receptor tyrosine kinase MET interactome and neurodevelopmental disorder partners at the developing synapse. Biol Psychiatry. 2016;80:933-42.

4. Judson MC, Bergman MY, Campbell DB, Eagleson KL, Levitt P. Dynamic gene and protein expression patterns of the autism-associated met receptor tyrosine kinase in the developing mouse forebrain. J Comp Neurol. 2009:513:511-31.

5. Qui S, Anderson CT, Levitt P, Shepherd GM. Circuit-specific intracortical hyperconnectivity in mice with deletion of the autism-associated met receptor tyrosine kinase. J Neurosci. 2011;31:5855-64

6. Lo FS, Erzurumlu RS, Powell EM. Insulin-independent GABAA receptormediated response in the barrel cortex of mice with impaired met activity. J Neurosci. 2016;36:3691-7.

7. Nelson SB, Valakh V. Excitatory/inhibitory balance and circuit homeostasis in autism spectrum disorders. Neuron. 2015:87:684-98.

8. Tatti R, Haley MS, Swanson OK, Tselha T, Maffei A. Neurophysiology and regulation of the balance between excitation and inhibition in neocortical circuits. Biol Psychiatry. 2016;81:821-31.

9. Gralle M. The neuronal insulin receptor in its environment. J Neurochem. 2017:140:359-67.

10. Werne $H$, LeRoith D. Insulin and insulin-like growth factor receptors in the brain: physiological and pathological aspects. Eur Neuropsychopharmacol. 2014;24:1947-53.

11. Vetiska SM, Ahmadian G, Ju W, Liu L, Wymann MP, Wang YT. GABAA receptor-associated phosphoinositide 3-kinase is required for insulininduced recruitment of postsynaptic GABAA receptors. Neuropharmacology. 2007:52:146-55

12. Accardi MV, Brown PM, Miraucourt LS, Orser BA, Bowie D. a6-containing GABAA receptors are the principal mediators of inhibitory synapse strengthening by insulin in cerebellar granule cells. J Neurosci. 2015;35:9676-88.

13. Kawaguchi-Suzuki M, Frye RF. Current clinical evidence on pioglitazone pharmacogenomics. Front Pharmacol. 2013;4:147.

14. Boris M, Kaiser CC, Goldblatt A, Elice MW, Edelson SM, Adams JB, Feinstein $\mathrm{DL}$. Effect of pioglitazone treatment on behavioral symptoms in autistic children. J Neuroinflammation. 2007:4:3.

15. Emanuele E, Lossano C, Politi P, Barale F. Pioglitazone as a therapeutic agent in autistic spectrum disorder. Med Hypotheses. 2007:69:699.

16. Doyle CA, McDougle CJ. Pharmacotherapy to control behavioral symptoms in children with autism. Expert Opin Pharmacother. 2012;13:1615-29.

17. Read S, Wu P, Biscow M. Sustained 4-year cognitive and functional response in early Alzheimer's disease with pioglitazone. J Am Geriatr Soc. 2014;62:584-6.

18. Ghaleiha A, Rasa SM, Nikoo M, Farokhnia M, Mohammadi MR, Akhondzadeh S. A pilot double-blind placebo-controlled trial of pioglitazone as adjunctive treatment to risperidone: effects on aberrant behavior in children with autism. Psychiatry Res. 2015;229:181-7.

19. Galimberti D, Scarpini E. Pioglitazone for the treatment of Alzheimer's disease. Expert Opin Investig Drugs. 2017;26:97-101.

20. Hsu D, Marshall GA. Primary and secondary prevention trials in Alzheimer's disease looking back, moving forward. Curr Allzheimer Re. 2017;14:426-40.
21. Agmon A, Connors BW. Thalamocortical responses of mouse somatosensory (barrel) cortex in vitro. Neuroscience. 1991:41:365-79.

22. Lee LJ, Iwasato T, Itohara S, Erzurumlu RS. Exuberant thalamocortical axon arborization in cortex-specific NMDAR1 knockout mice. J Comp Neurol. 2005:485:280-92.

23. Lee CC, Sherman SM. Synaptic properties of thalamic and intracortical inputs to layer 4 of the first- and higher-order cortical areas in the auditory and somatosensory systems. J Neurophysiol. 2008;100:317-26.

24. Agmon A, Connors BW. Correlation between intrinsic firing patterns and thalamocortical synaptic responses of neurons in mouse barrel cortex. J Neurosci. 1992:12:319-29.

25. Feldmeyer D, Egger V, Lubke J, Sakmann B. Reliable synaptic connections between pairs of excitatory layer 4 neurones within a single 'barrel' of developing rat somatosensory cortex. J Physiol. 1999;521(Pt 1):169-90.

26. Beierlein M, Gibson JR, Connors BW. Two dynamically distinct inhibitory networks in layer 4 of the neocortex. J Neurophysiol. 2003;90:2987-3000.

27. Lo FS, Akkentli F, Tsytsarev V, Erzurumlu RS. Functional significance of cortical NMDA receptors in somatosensory information processing. J Neurophysiol. 2013;110:2627-36.

28. Lo FS, Blue ME, Erzurumlu RS. Enhancement of postsynaptic GABAA and extrasynaptic NMDA receptor-mediated responses in the barrel cortex of Mecp2-null mice. J Neurophysiol. 2016;115:1298-306.

29. Turrigiano G. Homeostatic synaptic plasticity: local and global mechanisms for stabilizing neuronal function. Cold Spring Harb Perspect Biol. 2012:4(1):a005736.

30. Rubenstein $J$, Merzenich MM. Model of autism: increased ratio of excitation/ inhibition in key neural systems. Genes Brain Behav. 2003;2:255-67.

31. Gogolla N, Leblanc JJ, Quast KB, Südhof TC, Fagiolini M, Hensch TK. Common circuit defect of excitatory-inhibitory balance in mouse models of autism. J Neurodev Disord. 2009;1:172-81.

32. Mihalas AB, Hevner RF. Control of neuronal development by T-box genes in the brain. Curr Top Dev Biol. 2017:122:279-312.

33. Tong XJ, Hu Z, Liu Y, Anderson D, Kaplan JM. A network of autism linked genes stabilizes two pools of synaptic GABA(a) receptors. elife. 2015;4:e09648.

34. Tang W, Thevathasan JV, Lin Q, Lim KB, Kuroda K, Kaibuchi K, et al. Stimulation of synaptic vesicle exocytosis by the mental disease gene DISC1 is mediated by $\mathrm{N}$-type voltage-gated calcium channels. Front Synaptic Neurosci. 2016:8:15

35. Fafalios A, Ma J, Tan X, Stoops J, Luo J, DeFrances MC, Zarnegar R. A hepatocyte growth factor receptor (met)-insulin receptor hybrid governs hepatic glucose mechanism. Nat Med. 2011;17:1577-84.

36. Zhang Y-Y, Li C, Yao G-F, Du L-J, Liu Y, et al. Deletion of macrophage mineralocorticoid receptor protects hepatic steatosis and insulin resistance through Era/HGF/met pathway. Diabetes. 2017;66:1535-47.

37. Wei H, Ma Y, Ding C, Jin G, Liu J, Chang Q, et al. Reduced glutamate release in adult BTBR mouse model of autism spectrum disorder. Neurochem Res. 2016:41:3129-37.

38. DeLorey TM, Handforth A, Anagnostaras SG, Homanics GE, Minassianm BA Asatourian A, et al. Mice lacking the beta3 subunit of the GABAA receptor have the epilepsy phenotype and many of the behavioral characteristics of Angelman syndrome. J Neurosci. 1998:18:8505-14.

39. Homanics GE, DeLorey TM, Firestone LL, Quinlan JJ, Handforth A, Harrison $\mathrm{NL}$, et al. Mice devoid of gamma-aminobutyrate type a receptor beta3 subunit have epilepsy, cleft palate, and hypersensitive behavior. Proc Natl Acad Sci U S A. 1997:94:4143-8.

40. El Idrissi A, Ding XH, Scalia J, Trenkner E, Brown WT, Dobkin C. Decreased $\mathrm{GABA}(\mathrm{a})$ receptor expression in the seizure-prone fragile $X$ mouse. Neurosci Lett. 2005:377:141-6.

41. Gantois I, Vandesompele J, Speleman F, Reyniers E, D'Hooge R, Severijnen LA, et al. Expression profiling suggests underexpression of the GABA(a) receptor subunit delta in the fragile $X$ knockout mouse model. Neurobiol Dis. 2006:21:346-57.

42. Adusei DC, Pacey LK, Chen D, Hampson DR. Early developmental alterations in GABAergic protein expression in fragile $X$ knockout mice. Neuropharmacology. 2010;59:167-71.

43. Wan Q, Xiong ZG, Man HY, Ackerley CA, Braunton J, et al. Recruitment of functional GABA(a) receptors to postsynaptic domains by insulin. Nature. 1997;388:686-90.

44. Mielke JG, Wang YT. Insulin exerts neuroprotection by counteracting the decrease in cell-surface GABA receptors following oxygen-glucose deprivation in cultured cortical neurons. J Neurochem. 2005:92:103-13. 